\title{
Chapter 2 \\ Equity, Equality and Diversity-Putting Educational Justice in the Nordic Model to a Test
}

\author{
Nils Buchholtz $\mathbb{D}$, Amelie Stuart, and Tove Stjern Frønes
}

\begin{abstract}
Equity, equality and diversity are often linked to educational policy within the Nordic countries in the form of goals and principles. This can be traced back to the common educational tradition of these countries within the Nordic model of education. Because the terms are often used interchangeably, it seems appropriate to first grasp the theoretical and philosophical understanding of the terms before concrete educational policy measures can be assessed regarding to these goals. The chapter provides an overview of the terms and concretises educational policy measures to achieve equity, equality and diversity in the context of the Nordic countries. Today, societal developments and political changes call into question the common ground of the Nordic countries when it comes to matters of educational equity. Among other things, it will be discussed what contribution large scale international comparative studies can make to understanding equity, equality and diversity.
\end{abstract}

Keywords Equity $\cdot$ Equality $\cdot$ Diversity $\cdot$ School for all $\cdot$ Nordic model of education $\cdot$ Educational justice $\cdot$ ILSA

The Nordic model of education and its idea of a "School for All" is recognised by various parties as a realisation of greater equity (Blossing, Imsen, \& Moos, 2014; Telhaug, Mediås, \& Aasen, 2006). But equity can refer to various aspects of the educational policy discourse, and it is not always synonymous with equality,

\footnotetext{
N. Buchholtz $(\bowtie) \cdot$ T. S. Frønes

Department of Teacher Education and School Research, University of Oslo, Oslo, Norway e-mail: N.f.Buchholtz@ils.uio.no
}

A. Stuart

Max Weber Centre for Advanced Cultural and Social Studies, University of Erfurt,

Erfurt, Germany 
especially when it comes to the question of the realisation of life chances and educational justice. Furthermore, the classroom today is no longer as homogeneous as it was when the model was developed in light of experiences of common solidarity among the Nordic countries. So, what do equity and equality mean in the "School for All" today? Increased diversity among students suggests that the "All" has changed in the "School for All", and that the idea of equity is today confronted with changed and more differentiated individual needs. Thus, if the Nordic model is to maintain its idea of a "School for All", then the "School" must also change. When equity is used interchangeably with equality and thus means equal treatment by educational administrations, increased inequality in terms of needs is difficult to address, as some special needs might be overlooked or insufficiently resolved. In Norway, for example, education policy planning over the last decade has shifted from an understanding of "equity through equality", and thus standardisation and uniformity, to a new policy of "equity through diversity" with less dependency on central authorities (Solstad, 1997). Policy document analyses by Haugen (2010), however, reveal that how equity is understood and can be achieved is not a given and a matter of educational policies that are based on certain ideological groundings. This requires a theoretical and philosophical reflection on the concepts of equity, equality and diversity in education and how they are interpreted and implemented in educational policies in the Nordic countries. In this chapter, we will move from central philosophical theories on equity, equality and diversity in the international debate to how they mirror central features of the Nordic context.

A country's educational system plays a key role when addressing questions of fairness and equality. It lies at the centre of important normative questions concerning, for instance, equal opportunities for all members of society or respecting individual diversity. The prospect of equality of opportunities in education is a hope shared but also doubted by almost all education systems in the world. As political scientist Iris Young (2011, p. 21) notes with regard to the US:

\footnotetext{
While there are vast disagreements about why, almost no one in American society today thinks that educational opportunity is equal. There are vast and growing disparities in the quality of education to which Americans have access, and these shamefully track race and class $[\ldots]$. The turn-of-the-twentieth-century hope that public education can equalize the relationship among children of very unequal parents, giving each child an equal chance to compete with others from more privileged backgrounds, seems like a strange dream.
}

When policy makers intend to counterbalance or eradicate social and economic inequalities in order to achieve social justice, justice considerations with respect to the educational system must be addressed. This is because inequality is "manifested in the family environment, in occupational status and level of income; [and] it is also evident in educational opportunities, aspirations, attainment and cognitive skills" (Espinoza, 2007, p. 344). The main reason for looking at the impact of the educational system in this respect is, as Espinoza notes, that "educational systems [...] are involved in the reproduction and change of class relationships" (2007, p. 344). Thus, putting the question to an empirical study would mean first analysing which aspects and procedures within the educational system (implicitly) maintain 
or reproduce inequalities and then - starting from this analysis - working to develop policy measures to address the inequality and to change procedures.

In the first part of the chapter, we will focus on the theoretical underpinnings of the concepts of equity, equality and diversity in education, whereby we will reflect on the international origins of the respective discourses. As Espinoza points out, it is important to clarify the terminology when discussing matters of just and unjust equality (cf. Espinoza, 2007, p. 344). Drawing from his work on the concepts of "equality" and "equity", we will briefly introduce and discuss the main differences between these concepts and their relevance for our discussion of justice and equality of educational opportunity. For the discussion of educational justice, the concept of diversity also plays a role, which we will present in a complementary manner and place in the context of equity and equality. Vertovec $(2007,2010)$ describes diversity in contemporary societies as "super-diversity", pointing to a new and emerging complexity. According to Vertovec, this super-diversity involves several factors and comprises groups based not only on religion, country of birth and language, but also on the social rights and status achieved by different immigrant groups who have arrived at varying times and with different social statuses $(2007,2010)$. As we will see in the second part of the chapter, in the Nordic countries, this super-diversity is today matched with the legal counterpart of "inclusion". As an example, we will examine different approaches to establishing educational equity in the Nordic countries with regard to dealing with minority language students in order to concretize the previously elaborated concepts of equity, equality and diversity in different educational systems. The question of how united the Nordic countries are today with regard to a common Nordic model of education will be addressed in our final discussion.

\subsection{Equity and Equality in Educational Contexts}

In general, the concept of "equity" means being equal in quantity and quality and can be associated with justice in the sense of fairness, according to Espinoza (2007, pp. 344, 346). In this sense, individual circumstances and differences related to individual needs and requirements in the educational context are taken into consideration. The concept of "equality", on the other hand, can be associated with the idea of sameness in treatment, which is based on the normative ideal of the equality of all persons. It might seem that the implementation of "equality" would lead to more justice and equal opportunities within the educational context. However, we will show in which ways the concept of equity can provide further, important criteria for enhancing justice. We will therefore start our investigation of equality and equity with what is often seen as the most basic of the two concepts: equality. 


\subsubsection{Equality}

Von der Pfordten (2010) summarises the consequences of equality as a normative ideal as follows: "Every individual which has to be considered ethically must also be considered equally concerning her interests" (p. 201). According to von der Pfordten, there are essentially two options for assessing and evaluating the interests of those parties to be considered equally: equal treatment (e.g. concerning the allocation of resources or in taxation) and equality in society (e.g. when relating individuals to each other or to the society as a whole). However, apart from this formal consideration of equality, the material aspect of having the same opportunities to realise these claims is significant. As the economist and philosopher Amartya Sen points out, under conditions of extreme poverty, whether a child owns, for example, a bicycle could be the decisive factor in getting an education, because having a bicycle would ensure that the child can go to school even if the school is far away (cf. Sen, 1983).

In relation to this, the philosopher G.A. Cohen has emphasised that the focus on possessing rights is not sufficient. It is at least as important to ask whether a person actually has the opportunity to exercise these rights. Cohen therefore distinguishes between a "lack of freedom" and "unfreedom" (cf. Cohen, 1983). An example of this would be the right to freedom of movement, which is enjoyed by all citizens and which stands in contrast to the impossibility of exercising this right due to economic or other constraints. Here, the responsibility of the state is extended from merely guaranteeing citizens' rights to also working against the causes of this "unfreedom" of citizens. Another example to illustrate the concept, coming from education, would be the idea of national school curricula for equal educational attainment, no matter where students live or what kind of school they attend with respect to their abilities. The legal philosopher Martha Nussbaum similarly points out that guaranteeing rights is not enough for an autonomous, fulfilled life. What is crucial is a set of capabilities that every person must develop in order to be able to live out his or her rights (cf. Nussbaum, 2003, p. 37). Over the years, Nussbaum has compiled and supplemented a list of these capabilities. Among other things, this list is intended as a normative test for state action and governmental duties, since it is primarily the responsibility of a government to ensure conditions under which all citizens can develop their respective abilities. If these conditions are not properly in place or only partly fulfilled, then citizens will be unable to develop all their capabilities and will thus be prevented from leading happy and autonomous lives.

\subsubsection{Equity}

While the concept of equality in educational contexts can be discussed along the dimensions of access to education, educational provision and organisation, survival, output and outcome (cf. Antikainen, 2006; Espinoza, 2007; Farell, 1999), the 
concept of equity "demands fair competition but tolerates and, indeed, can require unequal results" (Espinoza, 2007, p. 346). This means that equality can be assessed quantitively by, for example, asking how many people in any given society have how much access to highly demanded goods. Equity, however, is assessed both quantitively and qualitatively, which means that it includes a moral judgment of a certain distribution of opportunities or goods. In this respect, it is much more difficult to assess equity because of, for example, subjective differences in how the quality and extent of inequalities are assessed (see Chap. 3). Despite this ambiguity, Espinoza attempts to provide an orientation: "The fundamental idea underlying the 'equity' theory is that fairness in social relationships occurs when rewards, punishments and resources are allocated in proportion to one's input or contributions" (2007, p. 348). Here, "input" refers to what an individual contributes to his or her success or the outcome of a process - for example, ambition or talents. But it is important to define what this means: a person's contribution. This needs to be addressed before questions of justice can be considered. We might ask: What counts as a person's natural gift and what does not? What (kind of) influence do virtues and vices, such as diligence or ambition, have on our assessment of these factors? For these issues, it is helpful to compare one individual's contribution in relation to the benefits he or she enjoys to the contributions and benefits of other individuals (Espinoza, 2007, p. 349), since this comparison might enable us to evaluate the fairness of the outcome (e.g. a person's allocated resources).

This outcome becomes manifest in the socio-economic background of a person, which is often described and measured as socio-economic status (SES). We could also describe socio-economic background as a person's position within a social structure. This position can be either advantageous and associated with benefits and opportunities or disadvantageous and associated with obstacles and discriminations. The assumption here is that each position within the social structure lends to each person specific possibilities and limitations. One proponent of this model is Iris Young. She assumes that societies can be depicted on the basis of a structural model. The way in which a social structure is built has very profound consequences for the opportunities and liberties of each member of society. Young borrows this structural model from sociology, referring to, for example, Pierre Bourdieu's field theory: "He conceives structures as 'fields' on which individuals stand in varying positions in relation to one another, offering possibilities for interpretation and action" (Young, 2006, p. 112) These so-called structures surround every human being and influence their freedom of action and their decision-making abilities. These structures also coordinate and shape collective action, and they are confirmed by the actual adherence to social norms, which are themselves based on this social structure.

If the effects of the structure within which a person finds himself or herself are disadvantageous, then according to Young, one could call this "structural injustice". Young defines this kind of injustice as follows:

The wrong is structural injustice, which is distinct from at least two other forms of harm or wrong, namely, that which comes about through individual interaction, and that which is attributable to the specific actions and policies of states or other powerful institutions. (2011, p. 45) 
This means that in the case of structural injustice, a person's limitations or disadvantages are caused neither by his or her own actions and decisions nor by governmental decisions or laws that would limit personal freedoms. Rather, structural injustice is influenced by the relative position a person has within the hierarchical social structure, a position which is based on access to, or control over, wealth, prestige and power (Mueller \& Parcel, 1981) and the possibilities and limitations resulting from this position. Initially, a person has no control over this position, as it is ascribed at birth. And yet, one's opportunities in life depend on this original position within the social structure. Correspondingly, the socio-economic status of a person is used in many studies on educational equity and equality as an important indicator for determining if a person belongs to a marginalised group. Willms and Tramonte (2019), for example, propose for educational research to investigate equity by examining differences among sub-populations with different SES in terms of their access to key measures of educational provision, such as quality instruction, taking up the perspective of distributive justice. On the other hand, equality can be studied if differences in student outcomes can be attributed to differences in SES, thus raising the perspective of equality. SES can be operationalised in studies in different ways (each with different explanatory power). Chapter 3 is therefore devoted to the different ways of measuring this construct statistically and how different statistical methods can be used to estimate equity (see Chap. 3).

The concept of equity, as introduced above, can be illustrated in this respect when we want to compare the status of one group or individual with the status of another group or individual. One example for this could be by looking at their access to higher education and by asking whether each member has the same access to higher education despite their different positions within the structure. It would therefore be insufficient to look only at the formal establishment of equal access.

The importance of this for justice considerations is addressed by John Rawls in the following way, describing the ideal of equality of opportunity:

The thought here is that positions are to be not only open in a formal sense, but that all should have a fair chance to attain them. Offhand it is not clear what is meant, but we might say that those with similar abilities and skills should have similar life chances. More specifically, assuming that there is a distribution of natural assets, those who are at the same level of talent and ability, and have the same willingness to use them, should have the same prospects of success regardless of their initial place in the social system. In all sectors of society there should be roughly equal prospects of culture and achievement for everyone similarly motivated and endowed. The expectations of those with the same abilities and aspirations should not be affected by their social class. (1999, p. 63)

This quote draws attention to one of the core aspects of educational justice: life chances. The right to education, which is guaranteed (for example in the Universal Declaration of Human Rights) to each child out of justice concerns, can be viewed as an instrument for enhancing a person's life chances. But there is a crucial difference between having the formal right to education and equal treatment and actually being able to make use of this right by, for example, being able to regularly attend school, as we have seen earlier. 
Thus, when looking for an answer to the initial normative question about overcoming inequalities, according to Rawls, a society would need the ideal of equality of opportunity for at least two reasons:

(1) The "outcomes of natural chance or the contingency of social circumstances" (Rawls, 1999, p. 11) need to be counterbalanced if they have a negative influence on the realisation of life plans. Equality of opportunity as an ideal of political decision making is important in cases when members of a community have an unequal share of benefits and burdens because they were born into unequal social positions, i.e. for contingent reasons.

(2) Equality of opportunity is needed to compensate for possible negative consequences and disadvantages if they are the result of certain individual decisions, e.g. starting a family.

Especially, this second reason shows that even though Rawls never uses the term "equity", he clearly has this concept in mind when he discusses the ideal of equality of opportunity, since he is very much concerned with individual circumstances and their relation to fairness.

In the Nordic countries, the idea of "education for all" has been particularly strong, as a basis for the Nordic welfare model, but also in the legal sense. Not only do students have the formal right to education - the right to access schooling - but all students, even those with special needs, have statutory rights to attend their local school and receive compulsory schooling up to 16 years of age (Imsen \& Volckmar, 2014). More remarkable in an international context is students' statutory right to adapted education and student-centred learning for equalisation and inclusion which can thus be linked to the concept of equity. The purpose clauses of the Nordic education systems are explicitly linked to equalisation - introduced to increase mobility in society and reduce differences among various groups, primarily social disparities (Imsen \& Volckmar, 2014, p. 46). Telhaug et al. (2006) show that this links back to the main goals of compulsory schooling in Nordic societies after the Second World War, namely to establish social virtues such as equal opportunity, cooperation, adaptation and solidarity.

\subsubsection{The Tension Between Equity and Equality}

What becomes clear from this consideration of equity and equality is the fact that these concepts are not necessarily complementary to one another - instead, there is a tension between them. Enhancing equity might not necessarily also enhance equality between the members of a society. As we have seen earlier, the concept of equity focuses on a fair distribution of highly demanded goods, whereas the concept of equality "is associated with the democratic ideal of social justice [and] demands equality of results" (Espinoza, 2007, p. 346). In other words: While the concept of equity focuses on distributive justice, the concept of equality mainly looks at procedural justice (e.g. when people are treated equally; Espinoza, 2007, p. 349; for a 
detailed discussion on distributive justice, see Lamont \& Favor, 2017). Consequently, the problem might arise that "if we wish to produce equal results, it is likely that we will need to generate an unequal distribution of resources" (Espinoza, 2007, p. 348). In other words: A policy aiming at greater equity within the educational system might entail a reduction of equality at the same time (cf. Espinoza, 2007, p. 346). Blossing et al. (2014, p. 7) give a concrete example for the possible dilemma in the education sector:

Should more resources be allocated to the most able pupils in order to maximise the national economic benefit of the school system, or is it more appropriate to channel more resources to those that are in need of the most help and support? If the distribution of resources is equal for all pupils, the result will probably be increasing social differences in educational outcomes, so this is an odd issue in the question of equity.

It is important to recall here that the concept of equality means, broadly speaking, sameness in treatment. This sameness does not necessarily also have to be just. For example, when we consider a group of different individuals with different needs or abilities, an equal treatment of all group members might not as a matter of fact be also regarded as "just", since some of them have certain needs that are not shared by all and, as a result, these members might need a treatment different from that of the rest of the group. In relation to this, we need to emphasise one aspect: Difference in treatment (and thus inequality) can be regarded as just only if it does not harm the other group members or puts them in a disadvantageous position compared to the position of the others (Rawls, 1999).

This example of a justified difference in treatment of certain members of a group is yet very much in accordance with the concept of equity, since it takes individual circumstances into account. In the context of education, we can see that in the concept of equity there lies a concern that students are different along several dimensions that have an impact on their need for learning and follow-up in the educational system. Opheim (2004) describes the need for fair learning environments, taking into account that most students are not alike. If all were alike, equity in education would simply be a question of providing an equal distribution of educational resources to all students - and thus it would turn out to be the concept of equality. But because students are different both individually and in the type and amount of resources they have obtained from their family and environment and which they bring with them into the classroom, their individual need for training will vary (Opheim, 2004), and therefore the concept of equity is needed.

\subsubsection{Diversity in Educational Contexts}

In the context of education, the tension between equity and equality must also be expanded by current educational policy challenges. Educational research is primarily concerned with the emergence and effects of inequality and selection in relation to educational pathways and in the social and economic sense. So far, we have 
outlined that, in relation to equity, distributive justice plays a role in the allocation of highly demanded goods (which sometimes leads to the acceptance of unequal distributions), and that the concept of equality refers to procedural aspects of justice in, for example, the dismantling of barriers to access to higher education. However, there is something missing. As Blossing et al. (2014, p. 7) point out: "Both equity and equality are terms that seem to be connected to the adjective equal, which is defined as being the same in quality, size, degree or value. These definitions miss the notion of being different, but of equal worth".

When looking at education, due to forms of migration, transnationalisation and hybridisation, other aspects of individuality and equality in educational contexts also come into focus (Robak, Sievers, \& Hauenschild, 2013). In addition to age, gender or socio-economic differences as a cause of structural inequality, there are other factors that play a role in the attribution of life chances, such as different cultural backgrounds, national-ethno-cultural (multiple) affiliations, cultural values, religions, languages, physical conditions and individual abilities (Robak et al., 2013, p. 15). Such forms of social diversification have increasingly been subsumed under the term "diversity" over the past 10 years (see Nestvogel, 2008; Prengel, 2013; Robak et al., 2013). While the concepts of equity and equality seem to be conceptually differentiated and refer to philosophical and sociological theories, the use of the term "diversity" has so far referred not so much to a unified concept as it has to a discourse that is concerned with the question of the appropriate political, legal, economic and educational handling of social diversity as influenced by particular theories (Hofmann, 2012; Robak et al., 2013).

With regard to one of the origins of the discourse, we will draw attention to the well-known context of diversity in the US. The political debate on diversity began in the US as early as the 1960s, when the so-called Grassroots Movement, the civil rights movement and the women's movement fought for equality at the workplace and in society (see Quaiser-Pohl, 2013). A central concern was the abolition of racial segregation in public schools. Even though African Americans were formally allowed to attend the same type of school as white students at that time, due to inequalities in housing and patterns of racial segregation in neighbourhoods, there were racially segregated "Black schools" that were worse equipped and harder to reach than schools for white people. Consequently, equality in education was one of the main themes of the movement, while the focus was placed on the categories of gender, race and class.

The attempt to assimilate the Sámi people in Norway can be seen as a complementary example from the Nordic countries (Gaski, 2008). Assimilation was an official Norwegian policy up until the Second World War, one which sought to compel Sámi people to discard their indigenous identity in favour of an ethno-national Norwegian identity and state citizenship (Gaski, 2008, p. 220). Gaski points to the results of this intensive policy of assimilation from the seventeenth century onwards, highlighting the radical decline in people who identified themselves as Sámi, extensive impoverishment, political powerlessness and a lack of knowledge about Sámi history and culture. A turning point for the political organisation of Sámi interests 
came in the 1950s, when a revitalization movement focused on the Sámi identity led to a new Sámi self-image (Jakobsen, 2011).

Even today, the concept of diversity in education is inextricably linked with the concept of equality (cf. Quaiser-Pohl, 2013; Volckmar, 2019). In addition to the education sector, in the economic sciences in the early 2000s, a so-called diversity management branch developed in reaction to increasing globalisation and internationalisation. In contemporary human resource management, the diversity of employees is used constructively as a resource to increase the efficiency and competitiveness of enterprises (cf. Robak et al., 2013). Concerning the US, contemporary researchers refer to the so-called "Big 8" as central categories for addressing diversity: race/ethnicity, gender, nationality, class/socio-economic status, age, sexual orientation, mental/physical ability and religion (Plummer, 2003; Quaiser-Pohl, 2013). This categorisation is also commonly used, albeit in varying forms, throughout the international research society.

In the educational sciences, Annedore Prengel brought together the political discourse, which stems from the anti-discrimination debate, and the utilitarian discourse on dealing with diversity in organisations. In her theoretical description of a resource-oriented diversity education, diversity is roughly understood as synonymous with difference and heterogeneity (Prengel, 2007, 2013). Using different categories of differentiation (such as ethnicity, gender and disability), Prengel describes how marginalised groups are discriminated against and socially marginalised, as well as how these groups fight for recognition as different and for overcoming difference. Thus, the term "diversity" comprises two levels: an analytical level and a normative level. Diversity is directed against discrimination based on attribution. The constitutional processes of the lines of difference vary in each case and must be reconstructed empirically in order to make them understandable and amenable to analysis (see Robak et al., 2013). In normative terms, this approach provides a power-critical analysis of exclusion based on attributions and, with the appreciation of the individuality of each person, also includes a bridge to the topic of inclusion (Prengel, 2013). Contemporary international large-scale assessment studies, such as PISA, address the issue of social diversity and operationalise the concept by looking separately at the performance of marginalised groups of students (e.g. with immigrant status or in terms of resilience) or by examining the variation in student performance both between and within schools (OECD, 2018). While more extensive aspects of heterogeneity and diversity are addressed here when measuring equity (cf. Chap. 3), students are still considered to belong to a certain risk group.

Although the concept of heterogeneity, according to its Greek etymology, describes the non-uniformity of the elements of a set and thus does not prescribe a hierarchy, the concepts of heterogeneity or difference can contain negative connotations, due to their duality, because they can be understood as a disturbance or deviation from assumed or expected homogeneity (Nestvogel, 2008, p. 21). The concept of difference is used by Prengel, however, to emphasise the uniqueness of individuals on the basis of different social criteria of difference (Robak et al., 2013). Diversity has a positive connotation because the term includes an appreciative attitude and openness to the differences of people. Moreover, according to UNESCO 
(2009), cultural diversity, also referred to as sociodiversity, is a concept that is regarded as a resource for innovation:

In a globalizing world, such changes are pervasive and make for the increased complexity of individual and group identities. Indeed, the recognition - and even affirmation - of multiple identities is a characteristic feature of our time. One of the paradoxical effects of globalization is thus to provoke forms of diversification conducive to innovation of all kinds and at all levels. (UNESCO, 2009, p. 28)

The term "diversity" has therefore increasingly replaced the concept of heterogeneity in educational debates. In the discourse on diversity, the terms "equal opportunities", "equal justice" and "educational justice" are frequently used, but their meanings are not always clear. The term "inequality", for example, is gradually being replaced by diversity, which leads to differentiation practices being increasingly discussed separate from political questions of distribution and justice, a trend which has been criticised (Hofmann, 2012, p. 30). In its normative orientation, the concept of diversity can be linked to Rawls' theory of justice. According to him, justice is to be understood as fairness, which refers to the freedom of the individual and equal opportunities based on performance:

(a) Each person has the same indefeasible claim to a fully adequate scheme of equal basic liberties, which scheme is compatible with the same scheme of liberties for all; and (b) Social and economic inequalities are to satisfy two conditions: first, they are to be attached to offices and positions open to all under conditions of fair equality of opportunity; and second, they are to be to the greatest benefit of the least-advantaged members of society (the difference principle). (Rawls, 2001, p. 42)

If all members of society are to be given the opportunity to freely choose and pursue their goals in life, then disadvantages in education must be eliminated by a compensatory redistribution of resources. However, overcoming these disadvantages, which are caused by contingencies such as a child's birthplace or cultural background, should not only address the segregation of groups in terms of performance characteristics, which can be countered, for example, by the provision of special educational measures, as Stojanov (2011) notes:

In negative terms, this means that the central manifestations of injustice in education are emotional neglect, disregard for subjectivity, and ignoring and disregarding the potential abilities of individuals. In this context, the isolated focus on achievement as an alleged criterion for the "fair" distribution of life chances in and through educational institutions appears to prevent insight into the actual target norms of educational justice. (p. 24, translated by the authors).

In concrete terms, this means that the unequal treatment of people with a migration background, for example, takes place because these people "are regarded as determined by their origin or as products of a family enculturation that is postulated to be deviant" (Stojanov, 2011, p. 42), and in the process experience a disregard. It therefore requires a shift in the educational policy discourse towards an appreciative recognition of diversity as a resource, one which can be seen and empirically analysed, for example, in the attitudes of teachers, changes in curricula, national school 
policy developments and the general strengthening of the autonomy of marginalised groups in education.

\subsection{Equality, Equity and Diversity in the Educational Systems of the Nordic Countries}

In the Nordic countries, the influence of multicultural and diverse groups on social and educational contexts has long been discussed. The experiences of the political reorganisations after the French Revolution and the Napoleonic Wars, but especially those of the Second World War, which were characterised by strong solidarity but also by political oppression, led to a socially, broadly supported understanding of democracy in the Nordic countries with high political participation and beliefs of equality. Equitable education was seen as one of the keys to achieving the goals of the Nordic welfare model. Accordingly, education for democracy, solidarity and social commitment was the core objective of educational policy in the following decades. Whereas the rural character of the Nordic countries was originally characterised by regional differences in education, each of these countries introduced state-controlled public comprehensive schools to varying degrees in the second half of the twentieth century (Antikainen, 2006; Blossing et al., 2014; Telhaug et al., 2006). From this, the Nordic countries developed the ideal model of a "School for All", which is also discussed in educational policy discourse under the term "Nordic Model of Education" (Lundahl, 2016; Telhaug et al., 2006). The model follows an egalitarian philosophy of the education of a classless society based on solidarity, which sees the task of nation-state action in the equalisation of social differences and recognises the extension of this task to the scholastic education of future generations. Correspondingly, the comprehensive schools gradually replaced forms of schooling based on organisational differentiation or ability grouping and consisted essentially of unstreamed, mixed-ability classes. Until the 1970s and 1980s, the implementation of the model was strongly influenced in the individual countries by long-lasting social democratic governments, which were established in parallel to the economic construction of welfare states based on the general principle of equality without large income disparities. At the same time, the cultural homogeneity of the population in the individual Nordic countries remained relatively stable during this period, with the exception of the historically developed treatment of cultural minorities, such that equity in the education system tended to relate mainly to the compensation of regional differences, gender differences or skills disadvantages (Blossing et al., 2014). However, the experience with work-related immigration movements since the 1970s has posed challenges for this orientation. As Blossing et al. (2014) note:

Since the mid 1980s new forms of governance and discourses have been introduced. Triggered by the entrance into and the competition on the global market place, all Nordic countries have brought political neoliberal thinking and governance, including new public 
management systems and social technologies, into their education systems, although in different ways and with different consequences for school practice. (p. 5)

The new neo-liberal and conservative policies of the 1980s and 1990s, which emphasised competition and individualism, have been discussed as being incompatible with the traditional egalitarianism of the Nordic countries (Blossing et al., 2014; Tjeldvoll, 1998). State intervention in the school system, decentralisation measures that allowed municipalities more freedom in allocating school resources, the handling of an increasing number of students with an immigration background, and stronger selection and segregation processes in the education system have all been discussed as effects of this change in educational policy. As a consequence, under the impression of growing social inequality in some Nordic countries, the model of the "School for All" and the extent to which it still corresponds to educational policy realities is currently a controversial topic (Antikainen, 2006; Blossing et al., 2014; Lundahl, 2016).

Coming back to our initial observation, despite the general orientation of the Nordic model of education with a "School for All", we indeed find differences between the countries in terms of how they understand equity and with regard to their strategies for coping with the increasing heterogeneity of their students. Some of these differences have partly arisen historically, such as the extent to which state action should guide the education sector, or how strongly the expansion of the comprehensive school system is linked to the formation of state identity and regional politics (Antikainen, 2006). In the following, we will present important educational policy measures and historical developments in the individual Nordic countries in connection with equity, equality and diversity when dealing with marginalised groups. The focus of our overview will be on dealing with national minority language students and students with an immigrant background. This issue is a benchmark across all Nordic countries facing similar challenges, as large percentages of immigrants in these countries tend to be concentrated in socioeconomically disadvantaged neighbourhoods and are overrepresented in "disadvantaged schools" (defined as schools with the highest proportion of students whose mothers have low levels of education) (see Quaiser-Pohl, 2013, p.17). Particularly, Norway, Sweden, Finland and Denmark have developed strong integration policies following increased immigration after 2000 and in light of the fact that 2 out of 5 immigrant students to these nations are socioeconomically disadvantaged (OECD, 2019a). Of course, with respect to our considerations of diversity thus far, we are aware that this is an inadequate reduction. We unfortunately cannot go into detail about all the educational policy backgrounds and measures that could be discussed in connection with diversity, such as the status of inclusion in schools or how to deal with students with special needs (Arnesen \& Lundahl, 2006; Egelund, Haug, \& Persson, 2006; Lundahl, 2016), the handling of religious plurality (Skeie, 2009), the processing of regional educational differences and inequality between schools (OECD, 2019a), or responses to gender differences, including the consistent female dominance in performance and academic attainment rates in the Nordic countries (OECD, 2012, 2019a; Pekkarinen, 2012). 


\subsubsection{The Case for Norway}

The educational system and its handling of cultural differences contributed greatly to Norway's development from a poor country to one of the richest nations in the world. The issue of dealing with linguistic minorities, such as Sámi people, in schools was raised as early as the eighteenth century in Norway (Engen, Kulbrandstad, Kulbrandstad, \& Lied, 2018). Increased immigration movements by workers from Pakistan, India and Turkey in the 1970s and the admission of Vietnamese, Chilean and Iranian refugees in the 1980s led to political discussions about cultural and linguistic homogeneity within the country. These discussions were initiated by the Norwegian Sámi Association and by strikes led by the Immigrant Children's Parents Union, which drew attention to the poor performance of their children in Norwegian schools. These political disputes in the early 1980s led to educational policy reforms regarding equal treatment and to the establishment of formal equality in education through changes in school curricula in 1987 (Engen et al., 2018). These changes guaranteed functional bilingualism for minority language students, but this was changed in the 1990s due to massive political pressure from the anti-immigration and pro-assimilation movement. From then on, minority language students lost the right to be taught in their mother tongue as soon as they had sufficient knowledge of Norwegian to be able to follow regular lessons (socalled transitional bilingualism). Municipalities were more or less free to provide such education, and mother tongue education is therefore clearly marginalised in Norway, with only $2-6 \%$ of all contemporary minority language students taking part in such education, although there are regional differences (Loona \& Wennerholm, 2017; Statistisk sentralbyrå, 2017). Today, immigration to Norway is comparatively moderate, although multilingual diversity is present at the classroom level in all urban areas. In early 2020, $18.2 \%$ of Norway's population were either immigrants or had immigrant parents (Statistisk sentralbyrå, 2020). Norway has a public school system that is divided into three levels: primary and lower secondary school, which is compulsory for students from 9-16 years of age, and three-year upper secondary school, including vocational schooling, which ensures the possibility of obtaining equivalent educational qualifications according to performance and ability. The comprehensive school system thus follows the social democratic and multicultural model of a "School for All", but despite the objective of levelling social inequality through education, studies have repeatedly confirmed that social differences in learning outcomes have been greater in Norway than in other, comparable countries due to the large gender gap found in the PISA assessment of reading literacy (OECD, 2019a; Opheim, 2004). Nevertheless, Norway is still among the countries with the lowest impact of socio-economic factors on student performance (OECD, 2012, 2019b), and there is no significant difference in the performance of disadvantaged students in either advantaged or disadvantaged schools (OECD, 2018). In Imsen and Volckmar's (2014) analysis of the Norwegian school system, they list a number of studies that indicate regional differences between schools due to the decentralisation policy in education in the $1990 \mathrm{~s}$, as well as studies that 
identify performance differences between social groups. In response, recent educational policies, such as the 2006 Knowledge Promotion Reform (Kunnskapsløftet), placed emphasis on adapted education and individualisation in teaching, which compelled teachers to devote much time to individual student support (Imsen \& Volckmar, 2014). Generally, globalisation and international comparison have put the Norwegian educational system continuously to the test. Over the last 20 years, therefore, the influences of neo-liberal education policies have been noticeable in the education sector, including consistent monitoring of student performance and educational outcomes through standardised achievement tests and early intervention in performance (Imsen \& Volckmar, 2014). Current surveys show that the performance of immigrant students across all school types is still significantly lower than that of other students (OECD, 2018), although there are differences in their performance in reading or English, and there is a tendency for second-generation immigrant students to partly overcome their disadvantages (Statistisk sentralbyrå, 2017). Boys from immigrant families are, however, identified as a particularly disadvantaged group, as they have comparatively lower rates of completion of regular secondary schooling and are also less likely to take up university studies (Statistisk sentralbyrå, 2017).

\subsubsection{The Case for Sweden}

After the Second World War, equality and diversity have been explicit goals in the Swedish education system in terms of core values to be taught (e.g. Husén, 1989; Rosén \& Wedin, 2018; SOU, 2014). From being one of the world's most centralised school systems, the Swedish school system has been transformed since the early 1990s into one of the world's most decentralised (Gustafsson, et al. 2014). The organisation and governance of Swedish schools changed radically when the responsibility for carrying out education was decentralised to municipalities and independent principals and a new state school administration was created. Gustafsson et al. (2014) especially emphasise how the "School for All" was challenged by the deregulated distribution of resources, freedom of choice between municipal and independent schools, free establishment in the school market with tuition fees as financial incentives, and a new grading system. The independent school reform in 1992 allowed private profit-making school providers to enter the education sector (Lundahl, 2016). These publicly funded, privately run independent schools have become a substantial part of contemporary schooling: $15.2 \%$ of compulsory school students and $27.6 \%$ of upper secondary school students attended such schools in 2018-2019. In the early 1990s, Sweden implemented the free school choice policy, allowing students to choose the school of their preference. Such a policy breaks with the former proximity principle of recruiting students with the intention of promoting equity and reducing residential segregation. However, empirical evidence has demonstrated the negative consequences of this policy on educational equity and justice, e.g. intensifying school segregation (e.g. Fjellman, 
Yang Hansen, \& Beach, 2018; Gustafsson et al., 2014; Söderström \& Uusitalo, 2010; Yang Hansen and Gustafsson, 2016).

During the 1960s and 1970s, Sweden was the first country in Europe to adopt the idea of multiculturalism in educational policy, and the social democratic policy of Olof Palme strengthened the cultural autonomy and mother tongue education for immigrant students in Sweden (cf. Loona \& Wennerholm, 2017). With increasing work-related immigration movements in the 1980s and the rise of asylum seekers in the 1990s (immigrants mostly coming from the Middle East, Latin America and former Yugoslavia), similar developments as in Norway applied to Sweden, and the society became more stratified (see e.g. Svanberg \& Tydén, 1999). In 2019, the proportion of the Swedish population with a foreign background (either immigrant or immigrant parents) was $25.5 \%$ (SCB, 2020), which is currently the highest among the Nordic countries. As early as 1983, an educational policy decree stipulated that schools adopt intercultural learning methods (SOU, 1983), which is in line with the Swedish notion of a "School for All", one based upon values of equality, community and integration (Egelund et al., 2006; Rosén \& Wedin, 2018, p. 58). Rosén and Wedin note this as a shift in discourse from a previous focus on multicultural education in terms of specific activities for children with migration backgrounds towards an intercultural education that includes all students. The policy changed slightly after economic crises in the 1990s. For example, state financial support for the municipalities was initially suspended, but since 2002 minority language students have again been supported in the acquisition of both languages by corresponding guidelines. However, the municipalities are relatively free to decide how and whether to provide appropriate services for minority language students (Loona \& Wennerholm, 2017). The formal right to mother tongue instruction for minority language students in Swedish schools is at present marginalised, as Loona and Wennerholm note, even if the proportion of minority language students taking part in this kind of instruction is still comparatively high, at 54\% (2017, p. 316). Possible reasons for this are the underfunding of the courses, a lack of teachers of Swedish as a second language, and the fact that such school courses are offered peripherally - for example, at off-peak times after school hours. The Swedish school system is a public comprehensive compulsory system and consists of both primary and lower secondary education. Few students also attend a special equivalent Sámi School for the first six years. A non-compulsory three-year strand of upper secondary education follows, attended by $99 \%$ of the age cohort (Båvner, Barklund, Hellewell, \& Svensson, 2011).

School curricula are set centrally in Sweden, schools and student performance are monitored centrally by school inspections and national tests, and classes are made up of mixed-ability classrooms in accordance with the political approach (e.g. Blossing \& Söderström, 2014). The analyses of Eklund (2003) on how diversity has been handled in education in Sweden since 1960 show, however, that there is a mismatch between the political aims of a "School for All", the curriculum and the views of students when, for example, looking at findings on the school-related segregation of minority language student groups. The influence of the socio-economic background of students on their performance has increased over the past two decades 
(e.g. Gustafsson \& Yang Hansen, 2017) and is at the same level as other OECD countries and the highest among the Nordic countries (OECD, 2019b). PISA has consistently found that immigrant students constantly perform worse than their native peers, even when controlled for socio-economic background (OECD, 2019b). In addition, a large-scale admission reform in Stockholm, which introduced freedom of choice of schools based on grades alone, led to a significant increase in segregation by family background in 2000 , and especially segregation between immigrants and natives (Söderström \& Uusitalo, 2010). The approach of heterogeneous classes is repeatedly undermined by homogenisation within the schools through ability grouping, which is often used as an organisational solution to deal with students' learning differences (Båvner et al., 2011; Blossing \& Söderström, 2014), although according to a Swedish Skoleverket report, this has shown no effect on student performance (Skolverket, 2009). Blossing and Söderström (2014) conclude their analysis by stating that the Swedish school system with its political approach is today exposed to a neo-liberal educational policy that focuses strongly on educational output and therefore may lose sight of the establishment of equity. In Sweden in particular, this calls into question the idea of the Nordic model of education, which is also addressed in the discussion of the results of cross-national analyses in Chap. 3.

\subsubsection{The Case for Iceland}

Iceland also has a growing proportion of immigrants in its population, reaching $14.1 \%$ in 2019 (Statistics Iceland, 2019). Large groups of immigrants come from Poland, Lithuania, the Philippines and Thailand. However, immigration began somewhat later in Iceland than in the other Nordic countries, starting in the 1990s (Ragnarsdóttir \& Lefever, 2018). Consequently, there are still few students with foreign backgrounds in the Icelandic school system, but increased immigration is expected to change this in the coming years (Garðarsdóttir \& Hauksson, 2011; OECD, 2019b). Iceland has a compulsory public school system that spans preschool to higher education, with widespread enrolment in upper secondary level. In Iceland, equal access to education irrespective of gender, economic status, geographic location, religion, disability, and cultural or social background has been anchored in the Icelandic constitution since 1944. The school system changed by law to a comprehensive system with mixed-ability groups in 1974, no longer disadvantaging students in rural areas who had to take part in ambulatory schooling or students who were grouped according to their reading ability regardless of age. In their analysis of the Icelandic school system, Sigurðardóttir, Guðjonsdóttir, and Karlsdóttir (2014) describe the development of the understanding of the Icelandic concept of a "School for All", moving from creating equality for students in rural areas in the beginning to an inclusive school system at present. They also list aspects of equity achievements, like broad-based inclusion in school (less than $1 \%$ of students attend special schools), a national curriculum based on adapted teaching and the recent emphasis 
on individualised learning. Since English is widely spoken in Iceland, the Icelandic Language Council together with the Icelandic Ministry of Education, Science and Culture changed the official language policy in 2008 in an effort to increase exposure to the Icelandic language in the educational sector. The "Icelandic for Everything Language Policy" emphasised that all students who have a heritage language other than Icelandic have the right to receive instruction in Icelandic as a second language, and that all schools must have reception plans in place for minority language students (Jónsdóttir, Ólafsdóttir, \& Einarsdóttir, 2018; Ragnarsdóttir \& Lefever, 2018). As a result of these measures, Iceland is repeatedly recognised as having attained a high level of equity in education (OECD, 2012, 2019b; Sigurðardóttir et al., 2014). The success of these efforts must, however, be viewed in the national context. Since Iceland is in the group of countries where immigrants are either highly skilled or come from high-income countries (OECD, 2019a), socio-economic background is less a factor in immigrant children's school performance, and its impact has even been decreasing in recent years (OECD, 2018). However, the gap in reading performance between immigrant students and nonimmigrant students in the PISA is large (OECD, 2019a, 2019b). On the other hand, efforts to integrate immigrant students do not seem to have contributed to the envisioned equality in education, as shown by a study from 2011 on the educational success of migrants in Iceland (Garðarsdóttir \& Hauksson, 2011). The study showed that only about $60 \%$ of male and $40 \%$ of female immigrants pass a secondary school examination, far less than in other European countries (cited in Ragnarsdóttir \& Lefever, 2018). In general, the dropout rates from secondary school are comparatively high in Iceland (around 30\%), which Sigurðardóttir et al. (2014) see as a major challenge for Icelandic educational policy.

\subsubsection{The Case for Finland}

In Finland, compared to other Nordic countries, the proportion of people with a migrant background is comparatively low: $7.2 \%$ in 2018 (Statistics Finland, 2020). Similar to Iceland, immigration to Finland only started in the 1990s, with most immigrants coming from the former Soviet Union, e.g. Estonia. But it is not only immigration that creates a need for multiculturalism in the Finnish school system: both the Evangelical Lutheran Church and the Orthodox Church are established by law and enjoy special privileges. In this regard, students have the right to instruction based on their own religious affiliation. A minority of the Finnish population, 5.4\%, politically strengthened in their cultural autonomy already by the constitution of 1919 , speaks Swedish, and $0.03 \%$ of the population speaks Sámi (Graeffe \& Lestinen, 2012). Culturally, the impression of a relatively homogeneous population still exists, even though the Swedish minority attends its own schools and exists relatively parallel to the Finnish majority society (Holm \& Londen, 2010). A constitutional reform of 1999 guarantees minorities equality based on the principle of a multicultural state, which in the educational sector also embraces functional 
bilingualism and multiculturality for immigrant populations. Immigrant students are provided with special individual support measures to establish their schooling and learn Finnish and Swedish (Graeffe \& Lestinen, 2012). The government also recommends and enables the teaching of Finnish as a second language or teaching in the mother tongue, and it is estimated that about $75 \%$ of minority language students participate in such programmes (2012). After a multi-sectional school system was successively replaced by a fundamental school reform in the 1970s, Finland implemented a nine-year, single-structured comprehensive school system. Since 2004, but even more so with the new curriculum that came into effect in 2016, the national curriculum is based on the model of Finland as a multi-ethnic state and take into account multicultural, intercultural and international education (Räsänen, 2007; Rühle, 2015). However, the excessively narrow definition of cultural diversity, the formulation of only particular educational goals for individual minority groups instead of universal goals for all students, and the failure to take other aspects of diversity into account are the object of criticism that the political orientation towards multiculturalism is intended as a "one-way process" and is related primarily to the hegemonic integration of immigrants into the majority society (Holm \& Londen, 2010; Zilliacus, Holm, \& Sahlström, 2017; see also Rühle, 2015). At 5.8\%, Finland currently has only a small proportion of immigrant students in education, like Iceland. Since immigrants from the former Soviet Union tend to be better educated than the average population, Finland has, in recent years, been able to demonstrate how well minority language students are integrated in the education system. International large-scale studies, such as PISA, have shown that immigrant students in Finnish schools perform significantly better than immigrant students in other countries (Graeffe \& Lestinen, 2012). However, the performance differences between immigrant students and their native peers are the largest among the Nordic countries, not least because of the good performance of Finnish students (OECD, 2019b). Gender differences in student performance in Finland are also the largest among the Nordic countries, preferring girls (OECD, 2019b). Ahonen (2014) suspects the consequences of deregulation of school financing as the root of these findings, as many schools have cut financial resources for remedial teaching. In his analysis of the Finnish school system, Ahonen further shows the influences of neoliberal education policy in Finland since the 1990s. For example, the introduction of marketisation and parental choice of primary schools has led to increasing segregation and polarisation between schools with respect to socio-economic background, which is also reflected in a widening gap between schools in PISA, at least between 2000 and 2009 (Ahonen, 2014).

\subsubsection{The Case for Denmark}

Denmark, too, had experience with guest workers from Southern and Eastern Europe, the Middle East and Asia as early as the 1960s and 1970s, whose families are now part of the Danish population. At the beginning of 2020, $13.8 \%$ of the 
Danish population had a migrant background (Statistics Denmark, 2020). However, there is a clear disadvantage in the academic performance of students with a migrant background. Immigrant students from a non-western background perform less well than their native peers in standardised tests, even when controlled for socioeconomic status (Houlberg, Andersen, Bjørnholt, Krassel, \& Pedersen, 2016; OECD, 2019b; Rangvid, 2010). Against this background, however, the liberalconservative Danish education policy of the last 20 years - strongly influenced by the right wing Dansk folkeparti (The Danish People's Party) - has been pursuing a strictly hegemonic course in the sense of a Danish unified culture since the mid-2000s (Horst \& Gitz-Johansen, 2010). On the one hand, this can be seen, for example, in the fact that learning Danish as a second language is only offered individually and is autonomously initiated by school principals (Andersen et al., 2012; Houlberg et al., 2016). On the other hand, political influence can be seen in the distribution of minority language students to different school districts with a higher proportion of non-immigrant students, which has been controlled since 2006 by the largely autonomous municipalities. This was done because it was estimated that schools with a student population composed of 50\% immigrant students would experience a deterioration in academic performance (Calmar Andersen \& Thomsen, 2011). This system has been supported by changing governments, but as the scheme is still optional, only some municipalities have chosen to implement it. Overall, a relatively constant average percentage of $10-11 \%$ immigrant students at Danish schools has been observed over the years (Houlberg et al., 2016; OECD, 2019b). Although re-distribution is seen as a measure to establish educational equality, as is made clear in Horst and Gitz-Johansen's (2010) analysis of education policy documents from 2003-2005, the strategy conveys a reading of equality in the sense of a deprivation paradigm "where the interpretation of underachievement is closely related to the child's ethnicity, family and locality, including lower socio-economic status. This is mirrored in an absence of recognition of ethnic diversity as linguistic and cultural resources" (Horst \& Gitz-Johansen, 2010, p. 143). Denmark, with its Folkeskole, has a 10-year, non-streamed comprehensive public school system. Denmark also has a long tradition of students attending private schools (Lundahl, 2016), and a substantial proportion of students, 15\%, attend these schools (Rasmussen \& Moos, 2014). One reason for the increase in Danish students attending private schools is the many regional school closures in the first decade of the twenty-first century, following the 2007 municipalities reform.

Danish schools follow the model of the "School for All", which, as the analysis of the Danish school system by Rasmussen and Moos (2014) shows, has changed under the influence of Denmark's transformation from a welfare state after the Second World War to a globally competitive economy from the 1990s onwards. In 2004, for example, similar to Sweden, Danish education policy decrees focused more on the evaluation of student performance and established stronger governance in the education system by national agencies for quality assurance (Houlberg et al., 2016). Correspondingly, the Folkeskole Act from 2006 represented a reordering of the purposes of schooling, and the purpose of preparing Danish students for further education and work has accordingly been strengthened. Approximately at the same 
time, the schools' (and students') performances were made public, increasing competition between them. In addition, some schools have established special classes for talented students, which seems to reflect a soft form of ability grouping in the school system (Rasmussen \& Moos, 2014). The overall performance of Danish students varies across different programmes. For example, Danish students show mediocre to good performance in PISA, TIMSS and PIRLS (Houlberg et al., 2016), but their performance in information-related subjects surveyed in ICILS is clearly superior due to the broadly established technical infrastructure in Danish schools and the widespread integration of digital media in teaching (Bundsgaard, Pettersson, \& Puck, 2014). Similar to Sweden, the socio-economic background of Danish students has a much greater influence on school performance than in the other Nordic countries, although in recent years - as in Iceland - it has become much less significant. Thus, in international comparisons, Denmark is seen to have established equity in education (OECD, 2018).

\subsection{Discussion}

So, the question remains: How can diversity be maintained and respected while at the same time guaranteeing educational justice and equality of opportunity to all students?

If we look at how different educational systems address this question, we can observe that focusing solely on achieving homogeneity and assimilation through education seems to be problematic from the standpoint of diversity theories as well as from justice-based considerations. Achieving equality in this way becomes unjust if it comes at the expense of certain groups (Rawls, 1999). A pure homogenisation of differences fails to recognise the different individual needs that prevail in a diverse educational landscape and which can lead to segregation effects. What constitutes the shift of the idea of homogenisation in the education system can be seen, for example, in the No Child Left Behind orientation in the US debate on education. In the US, with the reform intended to attain equality of achievement between students, a large part of the resources was used to compensate for disadvantages such that disadvantaged students actually scored better in mathematical performance tests (Dee \& Jacob, 2010). However, the simultaneous threat of sanctions at the school level for failure to achieve the set goals led to so-called "teaching-to-thetest" effects and to the disadvantaging and blaming of schools with a high proportion of low-scoring students (Darling-Hammond, 2007). Generally, within individual school classes, an unequal distribution of resources can also lead to injustice, because high achievers are disadvantaged and are no longer adequately supported under the premise of promoting the disadvantaged. This, then, does not provide a fair learning environment for all groups of students. Some researchers argue that this focus on homogenisation is also present in some Nordic countries and educational policies. Lundahl (2016), for example, describes how the introduction of free choice of schools by parents has led to segregation processes, which in turn increases 
the differences between schools, and how special needs education is increasingly treated as a problem of management and accountability (and is therefore only seen as a deviation from the norm). Especially when it comes to examining the Nordic model of education in relation to its implementation of educational justice within the individual Nordic countries, we believe that several aspects are crucial, which we will discuss in the context of our previous consideration:

First, the terms "equity" and "equality" are not always used consistently in educational policy documents and, as Espinoza (2007) notes, are often confused or used interchangeably. The fact that the terms can be used in different ways, depending on the specific situation, means that the achievement of equity and equality can be interpreted and misinterpreted in many ways in educational policy documents. This makes it difficult to assess whether educational justice in the sense of the Nordic model has actually been achieved. Correspondingly, how equity and equality are operationalised and examined in empirical studies differs, with far-reaching consequences. As Blossing et al. (2014) critically note, OECD reports already speak of the achievement of equity when, for example, information about the realisation of educational opportunities is the outcome of a quantitative analysis of the socioeconomic background and its relation to achievements, especially when looking at different groups like immigrant students or disadvantaged students. In the context of scientific research into educational inequalities from the perspective of educational effectiveness, such a reduction is certainly justified (see Chap. 3), but it is clearly debatable whether this mirrors current diversity discourses and their proponents (who see themselves as being exposed to the danger of being led ideologically).

Second, the formal establishment of equity alone is not sufficient to meet the requirements of a moral evaluation of fairness. For example, it must be investigated how the provision of resources in the education system can enable disadvantaged social groups to claim the right to equal educational opportunities. Furthermore, which measures can ensure the acceptance of diversity as a resource for the education system, apart from focusing on student outcomes, must be analysed. A focus on outcomes does not provide findings on how disadvantaged social groups perceive themselves and their achievements in the education system, nor whether they are valued and given the necessary attention. Such indicators are, however, particularly relevant when - as envisaged in the Nordic model - it comes to the inclusion and participation of individuals in democratic nation states, since this is one of the factors that determines how someone will behave as part of society in the future.

Third, the disadvantageous and completely contingent background conditions of some children pose a responsibility for political decision makers, teachers and society in general. These agents must strike a balance between the demands of equality (sameness in treatment) and the demands of equity (fairness of access, procedures, output and outcome). For considerations of equal opportunity, it is a government's responsibility to guarantee to each and every child an equal right to education. But in order to achieve and foster equity and diversity, their responsibility is not only to guarantee formal rights. They also need to guarantee that all individuals have the capability to realise their rights and have the material resources to do so. As we have pointed out, especially for children, the availability of basic (learning) materials is 
crucial, and without them their education is impossible. This raises the question of what and how resources in education are to be used if equality of opportunities is to be achieved. An equal distribution of resources is not fair because needs are not equal. Since educational policy in the Nordic countries is increasingly based on the control and distribution of financial resources by the state, and since the educational systems of Nordic countries require considerable state resources more so than other European countries (Telhaug et al., 2006), the question of effectiveness is all the more important. However, this is not at all due to neo-liberal political considerations or the question of profitability, but is instead due to the interests of marginalised groups: How do political measures best reach those who need them? Do these measures really meet the needs of the disadvantaged?

Fourth, the orientation of educational policy in the Nordic countries towards key figures and its comparability in terms of international competition is criticised from various quarters, as this policy does not follow the original intention of equality but instead results in a stronger orientation towards school performance and stronger state governance (Blossing et al., 2014; Telhaug et al., 2006). However, the criticism fails to recognise that from the perspective of educational effectiveness, only the use of standardised and internationally comparable instruments makes it possible as objectively as possible to assess the performance of school systems and thereby give a non-biased indication of the level of achievement of equity and equality in the educational system, at least in part. The SES of students as a psychometric construct is defined in various large-scale studies using a conglomerate of different variables and is linked to students' performance in order to obtain scientifically justified statements. The index takes into account a wide range of information on parents' education, occupations, possessions, such as access to the Internet, the existence of a workplace or the number of books at home (OECD, 2019a; see also Chap. 3). From a justice perspective, this broad anchoring is to be welcomed: Despite all justified criticism of the oversimplification, the index takes into account - across all countries - whether the conditions for fulfilling the criterion of being able to pursue the formal right to education are met. At the same time, however, there is a danger that policy makers will rely too much on these indicators and will subsequently only work on changing them instead of changing the conditions that foster them.

Finally, there is still the potential to improve scientific research on equality and equity in order to provide a better basis for policy makers. For example, in light of current diversity concepts, it no longer seems appropriate to focus research on equity and equality on the attribution of immigrant student status, SES or gender differences. It is true that studies now differentiate more broadly between various marginalised groups, such as disadvantaged students, immigrant students, secondgeneration immigrant students or students-at-risk (OECD, 2019a). What reporting on equity and equality has in common across studies, however, is that ascriptions of being deviate from the norm are used and different groups are compared against each other. Group membership is without a doubt important for identifying the causes of inequalities but should be secondary in the description of equity. Thomsen (2013, p. 175) describes the consequence of this orientation towards attribution: 
The narrativisation of equity-as-equal outcomes and equal-opportunity-as-the-removal-ofbarriers has become in national policy the arithmetic equation of the distribution of goods/ benefits among population groupings in roughly the same proportion as they are in the wider society $[\ldots]$ It is a distributive notion of equity and social justice $[\ldots]$.

Thomsen bemoans that this notion suggests that "all those below the median/average are just 'behind' [...]. When students are homogenized in this way, difference becomes a problem rather than a potential resource and strength" (2013, p. 176). Individual efforts, talents, diligence as well as lack of ambition also need to be considered in order to reach a conclusive idea of educational justice. It is, as we have shown, a matter of considering these normative aspects together, over a long period of time, since the dynamics of the social structure need to be addressed when evaluating the benefits, opportunities, obstacles and discriminations experienced by children. Here, large-scale studies being conducted to support educational policy making in different educational systems are continuously striving to develop more inclusive constructs and standards for equity. These studies should not settle for mere descriptions of differences between different groups of students; rather, against the background of the diversity discourse, they should also find measures useful for accessing the justice and fairness aspect of educational equity (including the qualitative aspects). Furthermore, these studies also has the opportunity to emphasise the positive aspects of group attributions (such as resilience) and be used to identify potential avenues by which to use information about marginalised groups as a resource for achieving equity.

\section{References}

Ahonen, S. (2014). A school for all in Finland. In U. Blossing, G. Imsen, \& L. Moos (Eds.), The Nordic Education Model. A "School for All” encounters neo-liberal policy (pp. 77-93). Dordrecht, The Netherland: Springer.

Andersen, D., Jensen, V. M., Nielsen, S. S. Pedersen, K. C. Z., Petersen, D. S., \& Thorsen, K. M. (2012). Indsatser for tosprogede elever [Efforts for bilingual students]. Kortlægning og analyse, SFI - Det Nationale Forskningscenter for Velfærd, København.

Antikainen, A. (2006). In search of the Nordic model in education. Scandinavian Journal of Educational Research, 50(3), 229-243.

Arnesen, A.-L., \& Lundahl, L. (2006). Still social and democratic? Inclusive education policies in the Nordic welfare states. Scandinavian Journal of Educational Research, 50(3), 285-300.

Båvner, P., Barklund, A., Hellewell, A., \& Svensson, M. (2011). OECD - Overcoming school failur (Country background report Sweden). Regerninskansliet.

Blossing, U., Imsen, G., \& Moos, L. (2014). Nordic schools in a time of change. In U. Blossing, G. Imsen, \& L. Moos (Eds.), The Nordic Education Model. A "School for All" encounters neoliberal policy (pp. 1-14). Dordrecht, The Netherland: Springer.

Blossing, U., \& Söderström, M. (2014). A school for every child in Sweden. In U. Blossing, G. Imsen, \& L. Moos (Eds.), The Nordic Education Model. A "School for All" encounters neoliberal policy (pp. 17-34). Dordrecht, The Netherland: Springer.

Bundsgaard, J., Pettersson, M., \& Puck, M. R. (2014). Digitale kompetencer - IT i danske skoler $i$ et internationalt perspektiv [Digital competencies -IT in Danish schools in an international perspective]. Aarhus Universitetsforlag. 
Calmar Andersen, S., \& Thomsen, M. K. (2011). Policy implications of limiting immigrant concentration in Danish public schools. Scandinavian Political Studies, 34(1), $27-52$.

Cohen, G. A. (1983). The structure of proletarian unfreedom. Philosophy \& Public Affairs, 12(1), 3-33.

Darling-Hammond, L. (2007). Race, inequality and educational accountability: The irony of 'No Child Left Behind'. Race, Ethnicity and Education, 10(3), 245-260.

Dee, T. S., \& Jacob, B. S. (2010). The impact of No Child Left Behind on students, teachers and schools (Brooking papers of economic activity, pp. 149-207).

Egelund, N., Haug, P., \& Persson, B. (2006). Inkluderande Pedagogik i Skandinaviskt Perspektiv [Inclusive pedagogy in a scandinavian perspective]. Liber.

Eklund, M. (2003). Interkulturellt lärande. Intentioner och realiteter till svensk grundskola sedan 1960. Doctoral dissertation; Intercultural learning. Intentions and realities to Swedish primary school since 1960. Luleå University of Technology.

Engen, T. O., Kulbrandstad, L. I., Kulbrandstad, L. A., \& Lied, S. (2018). Education and diversity: Introduction of a multidisciplinary research group. In Norwegian perspectives on education and cultural diversity (pp. 2-37). Newcastle upon Tyne, UK: Cambridge Scholars Publishing.

Espinoza, O. (2007). Solving the equity - Equality conceptual dilemma: A new model for analysis of the educational process. Educational Research, 49(4), 343-363.

Farell, J. (1999). Changing conceptions of equality of education: Forty years of comparative evidence. In R. Arnover \& C. Torres (Eds.), Comparative education: The dislectic of the global and the local (pp. 149-178). New York: Rowan \& Littlefield.

Fjellman, A. M., Yang Hansen, K., \& Beach, D. (2018). School choice and implications for equity: The new political geography of the Swedish upper secondary school market. Educational Review, 71(4), 518-539.

Garðarsdóttir, Ó., \& Hauksson, G. (2011). Young immigrants and persons with immigrant background in islandic society and islandic schools 1996-2011. Netla: Online Journal on Pedagogy and Education. Special Edition - Menntakvika Conference 2011. http://netla.hi.is/ menntakvika2011/020.pdf

Gaski, L. (2008). Sami identity as a Discursive Formation: Essentialism and ambivalence. In H. Minde, L. Gaski, S. Jentoft \& G. Midré (Eds.), Indigenous Peoples: Self-determination, Knowledge, Indigeneity (pp. 219-236). Eburon Academic Publishers.

Graeffe, L., \& Lestinen, L. (2012). Towards multicultural education in Finland. In J. A. Spinthourakis, J. Lalor, \& W. Berg (Eds.), Cultural diversity in the classroom. A European comparison (pp. 109-128). Wiesbaden, Germany: Springer.

Gustafsson, J.-E., Cliffordson, C. \& Erickson, G. (2014). Likvärdig kunskapsbedömning $i$ och av den svenska skolan - problem och möjligheter [Equivalent assessment of knowledge in and by the Swedish school - problems and opportunities]. SNS Förlag.

Gustafsson, J.-E., \& Yang Hansen, K. (2017). Changes in the impact of family education on student educational achievement in Sweden 1988-2014. Scandinavian Journal of Educational Research, 62(5), 719-736.

Haugen, C. R. (2010). Equity and life-long learning: An analysis of White Paper no. 16 (2006/2007) of Norway. Scandinavian Journal of Educational Research, 54(4), 357-376.

Hofmann, R. (2012). Gesellschaftstheoretische Grundlagen für einen reflexiven und inklusiven Umgang mit Diversitäten in Organisationen [Social theoretical foundations for a reflexive and inclusive approach to diversity in organizations]. In R. Bendl, E. Hanappi-Egger, \& R. Hofmann, Diversität und Diversitätsmanagement (pp. 23-60). University of Vienna.

Holm, G., \& Londen, M. (2010). The discourse on multicultural education in Finland: Education for whom? Intercultural Education, 21(2), 107-120.

Horst, C., \& Gitz-Johansen, T. (2010). Education of ethnic minority children in Denmark: Monocultural hegemony and counter positions. Intercultural Education, 21(2), 137-151.

Houlberg, K., Andersen, V. N., Bjørnholt, B., Krassel, K. F., \& Pedersen, L. H. (2016). Country background report - Denmark. OECD Review of Policies to Improve the Effectiveness of 
Resource Use in Schools. Det Nationale Institut for Kommuners og Regioners Analyse og Forskning.

Husén, T. (1989). The Swedish school reform-Exemplary both ways. Comparative Education, 25(3), 345-355.

Imsen, G., \& Volckmar, N. (2014). The Norwegian school for all: Historical emergence and neoliberal confrontation. In U. Blossing, G. Imsen, \& L. Moos (Eds.), The Nordic Education Model. A "School for All" encounters neo-liberal policy (pp. 35-56). Dordrecht, The Netherlands: Springer.

Jakobsen, J. (2011). Education, recognition and the Sami people of Norway. In H. Niedrig \& C. Ydesen (Eds.), Writing postcolonial histories of intercultural education. Frankfurt, Germany: Peter Lang Publishing Group.

Jónsdóttir, K. L. S., Ólafsdóttir, S., \& Einarsdóttir, J. T. (2018). Linguistically diverse children in Iceland: Their family language policy and Icelandic phonological awareness. In H. Ragnarsdóttir \& S. Lefever (Eds.), Icelandic studies on diversity and social justice in education (pp. 7-38). Newcastle upon Tyne, UK: Cambridge Scholars Publishing.

Lamont, J., \& Favor, C. (2017). Distributive justice. In E. Zalta (Ed.), Stanford encyclopedia of philosophy (Winter 2017).. https://plato.stanford.edu/entries/justice-distributive/

Loona, S., \& Wennerholm, M. (2017). Heritage language education in Norway and Sweden. In O. E. Kagan, M. M. Carreira, \& C. Hitchens Chik (Eds.), The Routledge handbook of heritage language education: From innovation to program building (pp. 313-326). New York: Routledge.

Lundahl, L. (2016). Equality, inclusion and marketization of Nordic education: Introductory notes. Research in Comparative \& International Education, 11(1), 3-12.

Mueller, C. W., \& Parcel, T. L. (1981). Measures of socioeconomic status: Alternatives and recommendations. Child Development, 52(1), 13-20.

Nestvogel, R. (2008). Diversity studies und Erziehungswissenschaften [Diversity studies and educational sciences]. In GPJE (Ed.), Diversity studies und politische Bildung [Diversity studies and political education] (pp. 21-33). Schwalbach/Ts, Germany: Wochenschau Verlag.

Nussbaum, M. C. (2003). Capabilities as fundamental entitlements: Sen and social justice. Feminist Economics, 9(2-3), 33-59.

OECD. (2012). Equity and quality in education. Supporting disadvantaged students and schools. OECD Publishing. https://doi.org/10.1787/9789264130852-en.

OECD. (2018). Equity in education. Breaking down barriers to social mobility. OECD Publishing. doi:https://doi.org/10.1787/9789264073234-en.

OECD. (2019a). PISA 2018 results (Volume II): Where all students can succeed. OECD Publishing https://doi.org/10.1787/b5fd1b8f-en.

OECD. (2019b). PISA 2018 results. Combined executive summaries (Vols. I, II \& III). OECD Publishing. https://www.oecd.org/pisa/Combined_Executive_Summaries_PISA_2018.pdf

Opheim, V. (2004). Equity in education. Country Analytical Report Norway. Oslo: NIFU STEP rapport $7 / 2004$.

Pekkarinen, T. (2012). Gender differences in education. Nordic Economic Policy Review, 1, 165-195.

Plummer, D. L. (2003). Overview of the field of diversity management. In D. L. Plummer (Ed.), Handbook of diversity management (pp. 1-49). Lanham, MD: University Press of America.

Prengel, A. (2007). Diversity education - Grundlagen und Probleme der Pädagogik der Vielfalt. [Diversity education - Basics and problems of the pedagogy of diversity]. In G. Krell et al. (Eds), Diversity Studies. Grundlagen und disziplinäre Ansätze [Diversity studies. Foundations and disciplinary approaches] (pp. 45-67). Frankfurt am Main, Germany: Campus-Verlag.

Prengel, A. (2013). Geleitwort: Diversität und Bildung [Preface: Diversity and education]. In K. Hauenschild, S. Robak, \& I. Sievers (Eds.), Diversity education. Zugänge - Perspektiven Beispiele [Diversity education. Approaches - Perspectives - Examples] (pp. 11-15). Frankfurt am Main, Germany: Brandes \& Apsel. 
Quaiser-Pohl, C. (2013). Diversity in education and the concept of "diversity" as a topic for educational science studies. In C. Quaiser-Pohl, V. Ruthsatz, \& M. Endepohls-Ulpe (Eds.), Diversity and diversity management in education - A European perspective (pp. 9-22). New York: Waxmann.

Ragnarsdóttir, H., \& Lefever, S. (2018). Introduction. In H. Ragnarsdóttir \& S. Lefever (Eds.), Icelandic studies on diversity and social justice in education (pp. 1-6). Newcastle upon Tyne, UK: Cambridge Scholars Publishing.

Rangvid, B. S. (2010). Sourche country differences in test score gaps: Evidence from Denmark. Education Economics, 18(3), 269-295.

Räsänen, R. (2007). Education for intercultural, multi-levelled citizenship in Europe: The case of Finland. In H.-G. Kotthoff \& S. Moutsios (Eds.), Education policies in Europe. Economy, citizenship, diversity (pp. 221-237). München, Germany: Waxmann.

Rasmussen, A., \& Moos, L. (2014). A School for Less than all in Denmark. In U. Blossing, G. Imsen, \& L. Moos (Eds.), The Nordic Education Model. A "School for All” encounters neoliberal policy (pp. 57-75). Dordrecht, The Netherlands: Springer.

Rawls, J. (1999). A theory of justice. Cambridge, MA: Harvard University Press.

Rawls, J. (2001). In E. Kelly (Ed.), Justice as fairness. A restatement. Cambridge, MA: Harvard University Press.

Robak, S., Sievers, I., \& Hauenschild, K. (2013). Einleitung diversity education: Zugänge und Spannungsfelder [Introduction diversity education: Approaches and areas of tension]. In K. Hausenschild, I. Sievers, \& S. Robak (Eds.), Diversity education. Zugänge - Perspektiven Beispiele [Diversity education. Approaches - Perspectives - Examples] (pp. 15-35). Frankfurt am Main, Germany: Brandes \& Apsel.

Rosén, J., \& Wedin, A. (2018). Same but different. Negotiating diversity in Swedish pre-school teacher training. Journal of Multicultural Discourses, 13(1), 52-68.

Rühle, S. (2015). Diversität, Curriculum und Bildungsstrukturen. Eine vergleichende Untersuchung in Deutschland und Finland [Diversity, curriculum and educational structures. A comparative study in Germany and Finland]. Waxmann.

SCB. (Statistiska Centralbyrån). (2020). Befolkningsstatistik i sammandrag 1960-2019. https://www.scb.se/hitta-statistik/statistik-efter-amne/befolkning/befolkningenssammansattning/befolkningsstatistik/pong/tabell-och-diagram/helarsstatistik\%2D\%2Driket/ befolkningsstatistik-i-sammandrag/\#Fotnoter

Sen, A. (1983). Poor, relatively speaking. Oxford Economic Papers, 35, 153-169.

Sigurðardóttir, A. K., Guðjonsdóttir, H., \& Karlsdóttir, J. (2014). The development of a School for all in Iceland: Equality, threats and political conditions. In U. Blossing, G. Imsen, \& L. Moos (Eds.), The Nordic Education Model. A "School for All" encounters neo-liberal policy (pp. 95-113). Dordrecht, The Netherlands: Springer.

Skeie, G. (2009). Religious diversity and education. Nordic perspectives. Münster, Germany: Waxmann.

Skolverket., S. (2009). What influences educational achievement in Swedish schools? A systematic review and summary analysis. Stockholm, Sweden: Swedish National Agency for Education.

Söderström, M., \& Uusitalo, R. (2010). School choice and segregation: Evidence from an admission reform. The Scandinavian Journal of Economics, 112(1), 55-76.

Solstad, K. J. (1997). Equity at risk.Planned educational change in Norway: Pitfalls and progress. Oslo, Norway: Scandinavian University Press.

SOU. (1983). Olika ursprung - gemenskap in Sverige: Education for the vulnerable and culturally diverse. Main focus of the Språk- und kulturarvsutredningen. Liber/Allmänna forel.

SOU. (2014). Staten fär inte abdikera-om kommunaliseringen av den svenska skolan [The government must not abdicate - About the municipalization of Swedish school]. Utbildningsdepartementet.

Statistics Denmark. (2020). Immigrants and their descendants. https://www.dst.dk/en/Statistik/ emner/befolkning-og-valg/indvandrere-og-efterkommere/indvandrere-og-efterkommere 
Statistics Finland. (2020). Immigrants in the population. https://www.stat.fi/tup/maahanmuutto/ maahanmuuttajat-vaestossa_en.html

Statistics Iceland. (2019). Immigrants and persons with foreign background 2019. https://statice.is/ publications/news-archive/inhabitants/immigrants-and-persons-with-foreign-background-8903

Statistisk sentralbyrå. (2017). Hvordan går det med innvandrere og deres barn i skolen? [How are immigrants and their children doing at school?] https://www.ssb.no/utdanning/ artikler-og-publikasjoner/hvordan-gar-det-med-innvandrere-og-deres-barn-i-skolen

Statistisk sentralbyrå. (2020). Immigrants and Norwegian-born to immigrant parents. https:// www.ssb.no/en/befolkning/statistikker/innvbef

Stojanov, K. (2011). Bildungsgerechtigkeit. Rekonstruktionen eines umkämpften Begriffs [Educational justice. Reconstructions of a contested concept]. Springer.

Svanberg, I., \& Tydén, M. (1999). Ett mångkulturellt Sverige? [A multicultural Sweden?] In I. Svanberg \& M. Tydén (Eds.), I nationalismens bakvatten. Om minoritet, etnicitet och rasism [In the backwaters of nationalism. About minority, ethnicity and racism] (pp. 78-96). Lund, Sweden: Studentlitteratur.

Telhaug, A. O., Mediås, O. A., \& Aasen, P. (2006). The Nordic model of education: Education as part of the political system in the last 50 years. Scandinavian Journal of Educational Research, 50(3), 245-283.

Thomson, P. (2013). Romancing the market: Narrativising equity in globalising times. Discourse: Studies in the Cultural Politics of Education, 34(2), 170-184.

Tjeldvoll, A. (1998). Quality or equality? Scandinavian education towards the year 2000. In A. Tjeldvoll (Ed.), Education in the Scandinavian welfare state in the year 2000. Equality, policy and reform (pp. 3-23). New York: Garland.

UNESCO. (2009). UNESCO world report. Investing in Cultural Diversity and Intercultural Dialogue. UNESCO.

Vertovec, S. (2007). Super-diversity and its implications. Ethnic and Racial Studies, 30(6), 1024-1054. https://doi.org/10.1080/01419870701599465.

Vertovec, S. (2010). Towards post-multiculturalism? Changing communities, conditions and contexts of diversity. International Social Science Journal, 61(199), 83-95. https://doi. org/10.1111/j.1468-2451.2010.01749.

Volckmar, N. (2019). The enduring quest for equity in education: Comparing Norway and Australia. Scandinavian Journal of Educational Research, 63(4), 617-631.

Von der Pfordten, D. (2010). Normative ethik. De Gruyter.

Willms, J. D. \& Tramonte, L. (2019). The measurement and use of socioeconomic status in educational research. In L. E. Suter, E. Smith \& B.D. Denman (Eds.), The SAGE handbook of comparative studies in educational research ( $\mathrm{pp}$ 289-304). SAGE.

Yang Hansen, K., \& Gustafsson, J.-E. (2016). Causes of educational segregation in Sweden-school choice or residential segregation. Educational Research and Evaluation, 22(1-2), $23-44$.

Young, I. (2006). Responsibility and global justice. Social Philosophy and Policy, 23(1), 102-130.

Young, I. (2011). Responsibility for justice. New York: Oxford University Press.

Zilliacus, H., Holm, G., \& Sahlström, F. (2017). Taking steps towards institutionalizing multicultural education - The national curriculum of Finland. Multicultural Education Review, 9(4), 231-248. 
Open Access This chapter is licensed under the terms of the Creative Commons Attribution 4.0 International License (http://creativecommons.org/licenses/by/4.0/), which permits use, sharing, adaptation, distribution and reproduction in any medium or format, as long as you give appropriate credit to the original author(s) and the source, provide a link to the Creative Commons license and indicate if changes were made.

The images or other third party material in this chapter are included in the chapter's Creative Commons license, unless indicated otherwise in a credit line to the material. If material is not included in the chapter's Creative Commons license and your intended use is not permitted by statutory regulation or exceeds the permitted use, you will need to obtain permission directly from the copyright holder. 